ONLINE FREELANCING DURING THE COVID-19 PANDEMIC

\title{
When Motivation Becomes Desperation: Online Freelancing During the COVID-19 Pandemic
}

\author{
Michael Dunn ${ }^{1}$, Fabian Stephany ${ }^{2}$, Steve Sawyer ${ }^{3}$, Isabel Munoz ${ }^{3}$, Raghav Raheja ${ }^{3}$, \\ Gabrielle Vaccaro $^{1}$, and Vili Lehdonvirta ${ }^{2}$ \\ ${ }^{1}$ Department of Management \& Business, Skidmore College, NY \\ ${ }^{2}$ Oxford Internet Institute, University of Oxford, UK \\ ${ }^{3}$ School of Information Studies, Syracuse University, NY
}

\begin{abstract}
Author Note
Michael Dunn ๑ https://orcid.org/0000-0001-5171-7114

Fabian Stephany ๑ https://orcid.org/0000-0002-0713-6010

Steven Sawyer ๑ https://orcid.org/0000-0001-5277-5148

Vili Lehdonvirta ๑ https://orcid.org/0000-0002-6509-1703

We have no known conflict of interest to disclose.

Correspondence concerning this article should be addressed to Michael Dunn,

Skidmore College, 815 N. Broadway, Saratoga Springs, NY 12866. Email:
\end{abstract}

mdunn@skidmore.edu 
ONLINE FREELANCING DURING THE COVID-19 PANDEMIC

\begin{abstract}
This study combines market-level data about changes in jobs offered via online labor platforms and interviews with online freelance workers to highlight how freelancers are responding to the novel coronavirus's presence. We pursue this work recognizing that as the scope and breadth of the COVID-19 pandemic continues to grow, the implications to workers and labor markets are profound. Our focus on online labor markets and workers reflects our enduring interest in knowledge work, with a particular attention to precarious work. Market data show the dramatic shifts in work availability (supply) and the changes in worker availability (demand) as the United States' economy struggles with the initial burst of effects of a pandemic. Interview data reveal that freelance workers are aware of these shifts. These changes to already- precarious and market-driven work arrangements are magnified by the realities of balancing family members' changes in job status, working around children who are home from school, and re-organizing work and lives to account for the rapid onset and confusion of stay-at-home requirements and the uncertainty that is the core of the pandemic. Findings suggest work flexibility, which seems central to freelancer's motivation to pursue such work, is diminishing and instead freelancers are being driven by desperation rooted in the acknowledged precarity of their situation, magnified by the constellation of events reshaping their working arrangements. We further observe that these effects vary by occupation and are more keenly experienced by women freelancers, both of which warrant additional attention.
\end{abstract}

Keywords: Online labor markets; Occupations; Motivation; Freelance work; COVID-19; 
ONLINE FREELANCING DURING THE COVID-19 PANDEMIC

\section{When Motivation Becomes Desperation: Online Freelancing During the COVID-19 Pandemic}

Combining market-level data about changes in jobs offered via online work platforms and interviews with freelance workers who use one online work platform, we focus on freelancer workers' initial responses to the novel coronavirus's economic impacts in the United States. We pursue this work recognizing that as the scope and breadth of the global COVID-19 pandemic continues, the implications to workers and labor markets are profound. Conservative estimates of a contained global outbreak expect significant global macroeconomic impacts (Atkeson, 2020; McKibben \& Fernando, 2020). Early research further highlights distinct demographic and industry differences of the pandemic (Wenham et al., 2020; Stephany et al., 2020b).

We focus attention to online freelancers because of the precarity of their work arrangements. Online freelancers and the online labor markets where they seek work are a relatively recent subset of labor markets, seen by many as both a means to provide opportunities for workers seeking flexible employment arrangements - short term 'gigs' - and for organizations to help absorb market shocks (Kalleberg, 2003; Lehdonvirta et al., 2019). Freelance work is project-based: there is little commitment between employer and worker beyond the specifics of the project's contract (Wood et al., 2019). The online nature of their work makes them susceptible to greater competition by reducing barriers for other workers to enter and compete (Dunn, 2017). And, in countries like the U.S., online freelancers are independent contractors. This means they lack benefits like health care, retirement, leave, and other workplace protections afforded to full-time workers (ILO, 2016; McKay et al., 2019).

There are at least three reasons the findings we report will interest readers of this journal. First, online labor and the knowledge-and-expertise-based forms of such work that are embodied in freelancing, like many forms of precarious work, are framed by issues of motivation for, and 
ONLINE FREELANCING DURING THE COVID-19 PANDEMIC

uncertainty about, flexible work arrangements. Second, findings suggest motivation does not fully explain what these workers are doing. Third, findings also make clear that both gender and occupation magnify precarity. As such, findings deserve the attention of psychologists of work, of trauma, and those who focus on family relations.

The remainder of this research report is developed in four sections. First, we provide an overview of online labor markets and the motivation for workers to pursue these gigs. The next two sections contain insights drawn from market-level data about online freelance labor, and insights drawn from an ongoing panel study of freelance workers in the United States. The final section contains a discussion of these findings, followed by some contemporary conclusions.

\section{Background}

Focusing on freelance work secured online also means looking at online labor platforms

(and the online labor market), which is where freelancers find their work. Online labor platforms are websites that mediate between buyers (clients) and sellers (workers) of remotely deliverable cognitive work (Horton, 2010). Online labor platforms can be subdivided into freelancing platforms (eg. Upwork), where payment is on an hourly or milestone basis, and microtask platforms (eg. Amazon Mechanical Turk), where payment is on a piece rate basis (Lehdonvirta, 2018). Functionality provided by these platforms provides means to match clients and workers. This includes allowing clients to post projects for bidding and allowing freelancers to post resumes for clients to evaluate. Platforms also support the entire contractual engagement to include time tracking, monitoring, billing, and dispute resolution. Online labor platforms are sometimes called online gig platforms, but the work they support is distinct from Uber or Deliveroo, which involve physical on-site service delivery (Wood et al., 2019). 
ONLINE FREELANCING DURING THE COVID-19 PANDEMIC

\section{Pandemic's Potential Effects on Online Labor Supply and Demand}

With the COVID-19 pandemic impacting the world's economies, leading to a massive rise in unemployment in the United States, it is reasonable to expect impacts on the supply of labor on online labor markets. ${ }^{1}$ One possibility is the number of workers offering services online might increase because the pandemic and its countermeasures have led to record-high unemployment in many countries, freeing up skilled workers (del Rio-Chanona et al., 2020). Workers who were already offering hours online on top of their regular work (ie. moonlighting; Pesole et al., 2018) might increase the hours offered as a result of being laid off. On the other hand, the hours supplied online might decrease as a result of workers falling ill or having increased care and housework duties, as schools close or household members fall ill.

The pandemic can also be expected to influence the demand for online labor. Many companies in the U.S. use nonstandard workers as a flexible buffer that can be rapidly adjusted in the face of economic changes, protecting core workers in downturns (Kalleberg, 2003). Public policy responses to the pandemic have in many countries, and certainly in the U.S., led to an economic downturn of historic proportions. It is conceivable that companies could be cutting their use of online labor platforms to engage employees and longer-term contractors. Conversely, there may be several mechanisms that trigger an increase in demand for online labor. Given this surge of interest in remote work, it is conceivable that online labor markets are well-positioned to accommodate new needs. Companies looking to engage new contractors might now favor remote online contractors hired through web-based platforms. It is also possible that some companies

\footnotetext{
${ }^{1}$ Supply generally consists of two elements: the number of workers offering their services through online platforms, and the number of hours that they are willing to supply (Horton, 2010).
} 
ONLINE FREELANCING DURING THE COVID-19 PANDEMIC

might be moving existing contractor relationships to online labor platforms, in what is known as the "bring your own freelancer" model (Corporaal \& Lehdonvirta, 2017).

Depending how the online labor market responds to the COVID-19 pandemic, diametrically opposed outcomes are possible (Stephany et al., 2020). On the one hand, the number of jobs and opportunities could increase, leading to a higher earnings and greater job security. Alternatively, the supply of workers could increase, leading to greater competition for jobs, greater uncertainty for future prospects, and lower earnings. This suggests that one's motivation for completing gig work will likely determine how the individual workers are experiencing the changes in the labor market. In turn, this motivation to pursue work likely reflects these worker's dependence on freelancing for their economic survival.

\section{Motivations in Online Labor}

Worker motivation has been the focus of sustained scholarly attention for decades (e.g. Viteles, 1953; Vroom, 1964). Kanfer, Frese, and Johnson's (2017) review of this attention makes clear that motivation research generally falls into three categories driven by three distinct questions: (1) Individual or content-based theories: What desires, wants, and needs elicit action?

(2) Environmental or context-based theories: What role do environmental factors play in motivation? (3) Process or process-based theories: Through what psychological processes and mechanisms do person and environment factors affect the direction, intensity, and persistence of action? Content-based theories have focused on different types of motives including intrinsic motives (e.g. Deci, 1975), justice (e.g. Scott et al., 2009), and traits (e.g. Barrick \& Mount, 1991; Barrick et al., 2002). Context-oriented theories have focused on the features associated with the work environment (Meyer et al., 2010), including Hackman and Oldham's job characteristics model and related studies (Hackman \& Oldham, 1975; 1976; Humphrey et al., 2007; Oerlemans 
ONLINE FREELANCING DURING THE COVID-19 PANDEMIC

$\&$ Baker, 2018). Process-oriented theories focus on the cognitive and affective mechanisms that integrate inputs to form goals, plans, and intentions and regulate their abilities to accomplish their goals (Tuckman, 1965; McGrath, 1984; Kanfer et al., 2017).

Beyond what is already known about worker motivation, there are at least three additional challenges to consider when analyzing motivation in the face of an evolution of traditional employment relationships toward platform-mediated work (Kanfer et al., 2017; Jagabi et al., 2019). First, is the role of intrinsic motivation. For example, in their study of on-demand workers, Rockmann and Ballinger (2017) found that, to the extent on-demand work fulfills one's innate psychological needs, workers will develop intrinsic motivation. Furthermore, the fulfillment of the worker's psychological needs is an important driver of well-being at work (e.g., Turner et al., 2002; Wheatley, 2017). Second, to what extent is motivation moderated or mediated by control and agency? To this point, the central question is framed by worker agency relative to bureaucratic control and management prerogatives (per Vidal, 2013).

A third challenge to understanding what motivates workers in online labor is the autonomy and flexibility it affords (Malone, 2004; Horton, 2010; Gratton \& Johns, 2013; Kuek et al., 2015; Sundararajan, 2016; Wheatly, 2017). Early accounts highlighted how online gig work provides "a flexible working schedule [that] allows individuals to take better care of their families, continue to study, or start their own businesses while working and earning a salary" (Kuek et al., 2015). Recent accounts are more critical (see Wood et al., 2019b).

Understanding flexibility in online freelance work builds from other technology-enabled flexible working arrangements such as telework/telecommuting, flexitime, and flexplace, all important topics of scholarship since the 1990s (see Baltes et al., 1999). These literatures have identified potential advantages to flexible scheduling, such as reducing work-family conflict 
ONLINE FREELANCING DURING THE COVID-19 PANDEMIC

(Shockley \& Allen, 2007) and allowing paid work to be combined with life circumstances that prevent regular work (Silver \& Coldschejder, 1994). However, studies of the effects of flexible scheduling have often yielded ambiguous results (Baltes et al., 1999), calling into question what exactly is meant by flexible scheduling (Shockley \& Allen, 2007).

Relevant to the role of work flexibility to motivation, studies have begun to distinguish worker-controlled flexible scheduling from manager-controlled flexible scheduling (Henly et al., 2006). Many of the potential advantages of flexible scheduling are associated with workercontrolled flexibility, while manager-controlled flexibility is associated with the opposite effects, because from the worker's point of view it creates uncertainty and inhibits planning (Hyman et al., 2005; Lambert et al., 2012). And, the boundary between worker- controlled and managercontrolled flexibility is ambiguous as the practices of negotiating working times can be bound up in the power relations of the workplace (Lambert et al., 2012, Wood, 2016). For instance, Wood's (2016) supermarket workers were formally free to declare the hours that they were available to work. In practice, however, they had to accept disruptive shifts or risk no longer being offered work. Likewise, the freelance technical contractors studied by Barley and Kunda (2006) were formally free to set their own working hours. Yet, many worked through evenings and holidays because they believed that this would decrease their chances of being laid off and increase the chances of future contracts (see also Fraser \& Gold, 2001; Gold \& Mustafa, 2013).

Thus, while the early literature on flexible scheduling framed this as a matter of freedom from formal constraints such as mandatory working hours, more recent literature has emphasized structural factors on workers' ability to actually manage their time. Lehdonvirta's (2018) study of online gig workers concluded that a worker's ability to schedule their work was ultimately determined by two factors: how easily available the gigs were and how dependent the worker 
ONLINE FREELANCING DURING THE COVID-19 PANDEMIC

was on income from the gigs. If many gigs were available, then workers could schedule their

work relatively freely. But if gigs were scarce and the worker depended on income from the gigs, the worker had to remain constantly on call, ready to sign up for gigs as soon as they became available, before others took them (see also Wood et al., 2019b).

What all this work suggests can be summarized into three questions that guide our work and this research report: (1) In the face of rapid online labor-market changes, are online freelance workers even more motivated to pursue work? (2) How do the realities of online freelance workers' occupation, current work arrangements, and non-work obligations motivate their decisions to pursue work? (3) What does flexibility, a central tenet to freelancers' motivations, look like during times of economic shock, like the COVID-19 pandemic?

\section{Quantitative Evidence from the Online Labor Index}

We first draw on Oxford's Online Labor Index (OLI) for a macro-level assessment of how online labor markets are affected by the COVID-19 pandemic. The OLI is an index that measures the utilization of online labor platforms over time and across countries and occupations (Kässi \& Lehdonvirta, 2018; See Appendix for additional information on methodology). It serves a similar function as conventional labor market statistics on new vacancies. For this report, we examine the effects of the pandemic pertaining to the United States.

The OLI data provides a global perspective on online labor markets and helps make clear that online labor demand is unevenly distributed with regard to geographies, as shown in Figure 1. In 2020 , more than $40 \%$ of all global demand stems from the United States, while the second largest single country buyer of online labor is the United Kingdom with eight percent. These data suggest that the global online labor demand is shaped by the United States' demand. 
ONLINE FREELANCING DURING THE COVID-19 PANDEMIC

\section{Changes in Online Labor Demand}

As data in Figure 2 make clear, over the past several years, U.S. online labor demand has shown a clear seasonal pattern: demand drops during the year-end holiday season, and then rises again to reach a plateau in March, which normally persists until June. However, this is not the case for 2020. By mid-March, when the World Health Organization declared COVID-19 was a global pandemic, online labor demand in the U.S. was in steep decline relative to 2018 and 2019. Then, in April 2020 demand began to rise again, surpassing the usual level of previous years at comparable times. This suggests that U.S.'s online labor demand growth, after an initial drop, reflects a response to the pandemic's effects on job availability (that is, labor demand).

\section{Insights on Occupations in the United States}

The OLI data allow us to further dissect online labor market dynamics into six different occupations: Clerical and data entry, professional services, software development and technology, creative and multimedia, sales and marketing support, and writing and translation. For a more detailed description of these categories, see Kässi and Lehdonvirta (2018). To align the quantitative analyses with the subsequent insights from qualitative interviews, we simplify the six OLI occupational categories into three groups: (1) Administrative work ("clerical and data entry" and "professional services"), (2) Creative work ("creative and multimedia," "sales and marketing support," and "writing and translation") and (3) Technological work ("software development and technology"). In addition, we are also able to observe the number of registered worker profiles on a smaller set of online labor platforms. This can be used as an imperfect proxy for the number of workers offering services through online labor platforms.

Figure 3 shows the change in demand and registered workers in the United States. As we can see in the top panel, not all occupations experienced a drop in demand. Demand in creative work shrunk significantly as the pandemic unfolded. But requests for technological work remain 
ONLINE FREELANCING DURING THE COVID-19 PANDEMIC

largely unaffected and even started to rise in April, 2020. This finding aligns with the idea that the rapid push towards videoconferencing and other remote operations across companies has created additional demand for freelance IT specialists. The initial insights are also consistent with the idea that companies are cutting non-essential freelance contracts, such as marketing and sales campaigns, while maintaining freelance work essential for continued business operations, such as information technology support and services.

The lower panel of Figure 3 illuminates that the number of registered workers has remained on pre-pandemic levels for administrative work and has shown significant increases in workers registered for creative jobs (approximately 20\% growth between April and June 2020). In technology work, however, the number of registered workers has surged: there were about $60 \%$ more by the end of May than in pre-pandemic times.

\section{Competition for Online Jobs}

The ratios of registered workers per requested project for the three occupational groups in the U.S. are presented in Figure 4. Pre-pandemic, the workers-to-projects ratios differ across occupational groups. On average, at the beginning of the timespan, the ratio of workers to projects is roughly three times higher in administrative work than in creative work and almost four times higher than for technological jobs. This suggests that there is more competition for administrative jobs, on average, than for technology work. This aligns with the experiences expressed in the interviews of freelancers, as we discuss below.

During the first months of the pandemic this picture changes. Beginning in March, 2020 the ratio increases for all occupations. However, in contrast to administrative work, the increase in creative work is much steeper. In both occupational domains, the upwards trend slows down in May, with job competition in administrative work reaching pre-pandemic levels, while the 
ONLINE FREELANCING DURING THE COVID-19 PANDEMIC

worker-to-job-ratio in creative work remains higher than in February 2020. For technological work, developments are quite different. The ratio starts to increase in early March but the upward trend steadily continues until the end of the measured time span. By the end of May, competition, measured by the ratio of workers to projects, has increased by about $50 \%$ as compared to February 2020. Taken together, these findings indicate that job competition has increased during the crisis for creative work and for technology jobs. The competition in administrative work was less affected by the pandemic, and was relatively high before the crisis.

\section{Insights from interviews and surveys with freelance workers in the US}

Interview data come from an ongoing panel study of freelance workers located in the United States and seeking work online via the online labor platform Upwork. ${ }^{2}$ Beginning in midMarch, 2020, we asked freelancers how they were faring in the face of the COVID-19 pandemic. For this paper, we draw on an interim analysis of 68 freelancers, 30 of whom spoke with us since mid-March, reviewing interview transcripts, drawing on field notes, and looking to secondary sources for additional insight and triangulation (See Table 1 for summary statistics, See Appendix for additional information on methodology). ${ }^{3}$

Data from the panel study provide substantial evidence that suggest an overall decrease in worker-controlled flexibility. The effects cut across both long-term freelancers and new freelancers, and for both full-time and part-time freelancers. Freelancers indicated significantly more competition, resulting in both a decrease in the number of proposals accepted and a marked decrease in compensation, likely stemming from increased competition. A female freelancer

\footnotetext{
${ }^{2}$ Upwork is one of many online labor platforms and routinely seen as a dominant player. See http://upwork.com.

${ }^{3}$ For secondary sources, we looked at active sub-threads for experiences with platform work, generally, and Upwork, specifically, found in both the online platform Reddit and in relevant Facebook groups.
} 
ONLINE FREELANCING DURING THE COVID-19 PANDEMIC

reflects: "I think more people are trying to find online work because they're out of their normal jobs [...] I think there's a lot less work to go around than usual because everyone is scrambling to make money, either while they are at home because they can't go into their office, or while they're laid off [...]So this current state definitely makes it more difficult" [FPAC040720201].

Some freelancers reported that the new jobs and tasks being posted also reflect lower rates, leading to a sense that clients are taking advantage of workers during the pandemic: "[...] there is going to be a lot of taking advantage of workers and their need to put food on the table" [FPAC042620201]. Additionally, stable long-term clients who provided a dependable source of income are stopping current projects and not requesting new work: "The two [clients] that I lost due to this virus were long term. One of them I had been working with for approximately a year and the other one was several months, but I don't know what's going to go on with them, if they're even going to come back or anything" [FPAC042520202].

The interview data aligns well with both the market-level data presented in Figures 3 and 4 and the survey data collected from freelancers as summarized in Table 2 . These data show decreases in weekly earnings between $12 \%$ to $47 \%$ for freelancers, and significantly greater difficulty in securing work since the start of the pandemic. Our analysis provides evidence that routines around freelance work have also changed. With spouses and partners being laid off or having to work from home, and children also home due to prolonged day-care and school closures, survey data shows that $40 \%$ of respondents are experiencing changes in their work routines. More than a third of participants mention being responsible for caregiving during this time. These changes are requiring the freelancers to alter their own working arrangements and work availability as they have less time to pursue work. Overall, freelancers reported feeling less productive and more "scattered" with some having to shuffle work around to nights and 
ONLINE FREELANCING DURING THE COVID-19 PANDEMIC

weekends with kids home: "The other thing that has affected me is that my kids are home now, so I'm having to homeschool my two children on top of trying to stay productive and earn income for myself, so I'm definitely feeling it" [FPAC04222020].

The data also show that earnings loss varies by occupation. Those doing administrative work (admin) show the smallest decrease $(-12 \%)$, followed by creative workers $(-30 \%)$, then technology workers (-47\%). We asked before the pandemic and after the start of the pandemic how difficult it was to find work in their respective fields. Respondents report significantly greater difficulty in finding work as the pandemic unfolds, with technology workers seeing the greatest differences and admin workers seeing the smallest differences. Furthermore, respondents in the survey differed in the average number of jobs/proposals bid-on with admin bidding on more than $80 \%$ more jobs on a weekly basis than those in technology. These findings align with the data presented in Figures 3 and 4 showing greater numbers of workers registered per job available, suggesting greater competition per job.

Data also shows the differences in the way workers from different occupational categories engage with the work. Respondents in creative occupations, by a wide margin, had greater dependency on the wages from gig work (it was their primary source of income). Furthermore, while our data showed that the majority $(\sim 59 \%)$ of workers did not have health benefits, $70 \%$ of the respondents in the creative occupations did not have health benefits. Given that the economic shock that they are experiencing is driven by a virus-centered pandemic, the magnitude of their precarity is evident and likely leading to a greater feeling of desperation.

Data also highlight the possible gender differences associated with these findings. Research has shown that women are over-represented in the occupations associated with the admin and creative categories in this study (Foone et al., 2018). Foone et al. (2018) also found 
ONLINE FREELANCING DURING THE COVID-19 PANDEMIC

that women across the entirety of the Upwork platform earned significantly less per hour than the median man on Upwork, even when controlling for key variables such as work experience, highest education level, and job category. In addition, Foone et al. (2018) found that women's lower hourly bill rates were coupled with a higher number of total hours worked on the platform.

Moreover, it is continually re-established that women bear a greater share of domestic responsibilities (Barulescu \& Bidwell, 2012; Blau \& Kahn, 2016; Wiswall \& Zafar, 2018). During the current pandemic, these gendered differences in responsibility appear to be magnified in households with children because of the continued closure of schools and the lockdowns. Recent efforts to quantify the possible effects to households found that mothers are only able to do one hour of uninterrupted work for every three hours done by fathers. Mothers are also taking on more chores and spending more time with children in homes where there is both a working mother and father (Institute for Fiscal Studies, 2020). Likewise, mothers are more likely than fathers to have left paid work and experienced a larger reduction in their hours. Among those doing paid work at home, mothers are more likely than fathers to be spending their work hours simultaneously trying to care for children (Institute for Fiscal Studies, 2020). These findings are amplified in single-parent families with female heads of households. Our data are consistent with these findings.

\section{Discussion and Conclusion}

Our focus on online freelance work builds from an interest in the changing nature of work and employment, with a specific focus on precarity. The COVID-19 pandemic's impact continues to unfold around the globe and challenges most societies' ability to deal with the overlapping issues of health, safety, and economic viability. The research reported here focuses 
ONLINE FREELANCING DURING THE COVID-19 PANDEMIC

attention to the impact of this pandemic's disruption on the online labor market, specifically situated in the United States, which comprises the largest share of online labor demand.

The Online Labor Index data show the demand for online freelancers has recovered to pre-pandemic levels after a sharp dip, but all occupation categories are facing an increase in labor supply. The data also show the pandemic's effects impact occupational categories differently, with competition - measured by the ratio of workers to projects - steadily increasing for all occupations from March.

Results from interviews reinforce what is learned from the OLI data. Since the onset of the pandemic in the U.S., Upwork freelancers have faced increased competition and uncertainty about job security, as well as a decrease in compensation. These freelancers' circumstances are further complicated by the precarity that arises from the structural and legal nature of their work, including not being eligible for unemployment and lacking access to employer-provided healthcare. The precarity of freelance work is particularly pronounced among those in creative occupations. Creative workers are particularly vulnerable as they report a greater dependency on the wages from gig work and have the lowest reported access to health benefits. These workers also report greater unpredictability of weekly earnings and experienced the largest drop in hours spent across freelancing websites when comparing pre-COVID-19 data to post-COVID-19 data.

Panel study data suggests online freelance workers across all occupations are aware of the decreased supply of jobs and increased competition. Surprisingly, the data show the number of hours freelancers report working has decreased for all occupations since the start of the pandemic. We surmise the decrease in hours may be explained by the realities of freelancers having to re-balance their household lives. This includes accommodating the changing nature of work arrangements, with spouses and children who are home from school now competing for 
ONLINE FREELANCING DURING THE COVID-19 PANDEMIC

time and space in the household. The effects of re-configured family arrangements vary by occupation and have a greater effect for women freelancers' motivation and ability to do work. Building from this, we need to better understand the impacts of increased complexity and changes to household life during a crisis such as the COVID-19 pandemic, especially among women who are breadwinners.

Taken together, findings suggest that the concept of work flexibility, the primary motivating factor for pursuing this type of work, might be better characterized as work desperation. Motivated by flexibility, freelance workers pursue online work that fit with household arrangements. Such work is always precarious, as our data show. But this precarity seems a reasonable risk to preserve flexibility. Market shocks change the calculation in ways that seem to overwhelm motivation, leading workers to eschew flexibility as they scramble for work, even in the face of less flexible household arrangements and more demands.

As online freelancers continue to experience desperation amid increased work supply and lowering wages, they will likely succumb to market forces and continue to bid for more work, even when this strategy is not in their best interest. Desperation is increasingly visible among freelance workers as the open market conditions of online labor markets are exacerbated amid the COVID-19 pandemic. Attention to the roles of desperation, specifically with regards to the interdependencies between work and non-work responsibilities, seems like a fertile and discomforting research space for scholars of work.

\section{Conclusion}

Combining market-level and interview data, this research provides additional empirical and nascent conceptual insights into some of the impacts of COVID-19 on the online labor market and experiences of online freelancers. Data show that market shocks like that of COVID- 
ONLINE FREELANCING DURING THE COVID-19 PANDEMIC

19 lead to rapid changes in online labor markets and that these rapid changes reshape the ways in which freelance workers seeking work online frame and pursue their work.

The premise of flexibility, a key motivating factor for pursuing online freelance work, is challenged by these data. Findings show that flexibility for pursuing work is constrained by changes in people's household arrangements. And, the flexibility to select work that aligns with one's interests and schedules is challenged by the whipsaw changes in the competition for online work as magnified by the increase in the number of people seeking work online (more supply).

We are particularly keen to offer these insights to scholars of work, seeking to draw their expertise to better understand how the contemporary construction of worker motivation can accommodate the structure of precarious work and the context of economic shock. On this last, we see the COVID-19 pandemic as a powerful instance of economic shock. It may be a once-ina-lifetime economic shock, but it follows 12 years from the 2008 economic shock driven by financial greed, and stands as the current marker for the next shock.

As noted above, online labor markets are what Kalleberg (2003) calls a buffer space for companies to protect their full-time workers from economic shocks. Our data make clear what many have noted: this makes these labor markets a very difficult place and way in which to make one's living. As work becomes more precarious, how do we translate or interpret the current and extensive knowledge regarding the individual, environmental, and process-oriented mechanisms driving worker behavior and engagement (per Kanfer, Frese and Johnson, 2017)? 
ONLINE FREELANCING DURING THE COVID-19 PANDEMIC

\section{References}

Atkeson, A. (2020). What will be the economic impact of COVID-19 in the US? Rough estimates of disease scenarios (Working Paper 26867). National Bureau of Economic Research.

Barbulescu, R., \& Bidwell, M. (2012). Do Women Choose Different Jobs from Men? Mechanisms of Application Segregation in the Market for Managerial Workers. Organization Science (24)3, 737-756. https://doi.org/10.1287/orsc.1120.0757

Barley, S.R., \& Kunda G. (2006). Gurus, Hired Guns, and Warm Bodies: Itinerant Experts in a Knowledge Economy. (Princeton, NJ: Princeton University Press). https://doi.org/10.1515/9781400841271

Blau, F., \& Kahn, L. (2016). The Gender Wage Gap: Extent, Trends, and Explanations. Technical Report 21923. National Bureau of Economic Research. 1-77 pages. https://www.nber.org/papers/w21913.pdf

Barrick, M. R., \& Mount, M. K. (1991). The big five personality dimensions and job performance: A meta-analysis. Personnel Psychology, (44)1, 1-26. http://dx.doi.org/10.1111/j.1744-6570.1991.tb00688.x

Baltes, B.B., Briggs, T.E., Huff J.W., Wright, J.A., \& Neuman G.A. (1999). Flexible and Compressed Workweek Schedules: A Meta-Analysis of Their Effects on Work-Related Criteria. Journal of Applied Psychology (84)4, 496-513. https://doi.org/10.1037/00219010.84 .4 .496

Barrick, M. R., Stewart, G. L., \& Piotrowski, M. (2002). Personality and job performance: Test of the mediating effects of motivation among sales representatives. Journal of Applied Psychology, (87)1, 43-51. http://dx.doi.org/10.1037/0021-9010.87.1.43 
ONLINE FREELANCING DURING THE COVID-19 PANDEMIC

Corporaal, G.F., \& Lehdonvirta, V. (2017) Platform Sourcing: How Fortune 500 Firms are Adopting Online Freelancing Platforms. Oxford: Oxford Internet Institute.

Deci, E. L. (1975). Intrinsic Motivation. New York, NY: Plenum Press. http://dx.doi.org/10.1007/978-1-4613-4446-9

del Rio-Chanona, R. M., Mealy, P., Pichler, A., Lafond, F., \& Farmer, D. (2020). Supply and demand shocks in the COVID-19 pandemic: An industry and occupation perspective. arXiv preprint arXiv:2004.06759.

Dunn, M. (2017). Digital Work: New Opportunities or Lost Wages? American Journal of Management, 17(4), 10-27. https://doi.org/10.5465/ambpp.2016.11689abstract

Foone E., Vincent N., Hecht B., \& Gerber E. (2018). Women (Still) Ask For Less: Gender Differences in Hourly Rate in an Online Labor Marketplace. Proc. ACM Hum.-Comput. Interact. 2, CSCW, Article 53. https://doi.org/10.1145/3274322

Fraser, J., \& Gold M. (2001). Portfolio Workers': Autonomy and Control Amongst Freelance Translators. Work, Employment \& Society (15)4, 679-697. https://doi.org/10.1017/s0950017001006791

Gold, M., \& Mustafa M. (2013). "Work Always Wins": Client Colonisation, Time Management and the Anxieties of Connected Freelancers. New Technology, Work and Employment (28)3, 197-211. https://doi.org/10.1111/ntwe.12017

Gratton, L., \& Johns T. (2013). The Third Wave of Virtual Work. Harvard Business Review, January-February, 2-9.

Hackman, J. R., \& Oldham, G. R. (1975). Development of the job diagnostic survey. Journal of Applied Psychology, (60)2, 159 -170. http://dx.doi.org/10.1037/h0076546 
ONLINE FREELANCING DURING THE COVID-19 PANDEMIC

Hackman, J. R., \& Oldham, G. R. (1976). Motivation through the design of work: Test of a theory. Organizational Behavior and Human Performance, (16)2, 250 -279. http://dx.doi.org/10.1016/0030-5073(76)90016-7

Henly, J.R., Shaefer, H.L., \& and Waxman, R.E. (2006). Non-standard Work Schedules: Employer- and Employee-Driven Flexibility in Retail Jobs. Social Service Review (80)4, 609-634. https://doi.org/10.1086/508478

Horton, J. J. (2010). Online Labor Markets. In A. Saberi (Ed.), Internet and Network Economics (pp. 515-522). Springer: Berlin Heidelberg. https://doi.org/10.1007/978-3-642-17572$5+45$.

Humphrey, S. E., Nahrgang, J. D., \& Morgeson, F. P. (2007). Integrating motivational, social, and contextual work design features: A meta-analytic summary and theoretical extension of the work design literature. Journal of Applied Psychology, 92(5), 13321356. https://doi.org/10.1037/0021-9010.92.5.1332

Hyman, J., Scholarios, D., \& Baldry C. (2005). Getting on or Getting by? Employee Flexibility and Coping Strategies for Home and Work. Work, Employment and Society, (19)4, 705725. https://doi.org/10.1177/0950017005058055

International Labour Organization (2016). Non-standard employment around the world: Understanding challenges, shaping prospects. ILO Publications: Geneva. https://www.ilo.org/global/publications/books/WCMS 534326/lang--en/index.htm. Institute for Fiscal Studies. (2020, May 27). Parents, especially mothers, paying heavy price for lockdown [Press Release]. Retrieved from https://www.ifs.org.uk/publications/14861 
ONLINE FREELANCING DURING THE COVID-19 PANDEMIC

Jabagi N., Croteau A.M., Audebrand L.K., \& Marsan J. (2019). Gig-workers' motivation: thinking beyond carrots and sticks. Journal of Managerial Psychology 34(4): 192-213. https://doi.org/10.1108/jmp-06-2018-0255

Kalleberg, A. L. (2003). Flexible Firms and Labor Market Segmentation: Effects of Workplace Restructuring on Jobs and Workers. Work and Occupations, 30(2), 154-175. https://doi.org/10.1177/0730888403251683.

Kanfer, R., Frese, M., \& Johnson, R. E. (2017). Motivation related to work: A century of progress. Journal of Applied Psychology, 102(3), 338-355.

\section{https://doi.org/10.1037/ap10000133}

Kässi, O., \& Lehdonvirta, V. (2018). Online labour index: Measuring the online gig economy for policy and research. Technological Forecasting and Social Change, 137, 241-248. https://doi.org/10.1016/j.techfore.2018.07.056

Kuek, S.C., Paradi-Guilford, C., Fayomi, T. Imaizumi, S. Ipeirotis, P. Pina P., \& Singh M. (2015). The Global Opportunity in Online Outsourcing. (Washington, DC: World Bank).

Lambert, S.J., Haley-Lock, A., \& Henly, J.R. (2012). Schedule Flexibility in Hourly Jobs: Unanticipated Consequences and Promising Directions. Community, Work \& Family (15)3, 293-315. https://doi.org/10.1080/13668803.2012.662803

Lehdonvirta, V. (2018). Flexibility in the gig economy: Managing time on three online piecework platforms. New Technology, Work and Employment, 33(1), 13-29. https://doi.org/10.1111/ntwe.12102.

Lehdonvirta, V., Kässi, O., Hjorth, I., Barnard, H., \& Graham, M. (2019). The Global Platform Economy: A New Offshoring Institution Enabling Emerging-Economy Microproviders. Journal of Management, 45(2), 567-599. https://doi.org/10.1177/0149206318786781 
ONLINE FREELANCING DURING THE COVID-19 PANDEMIC

Malone, T.W. (2004). The Future of Work: How the New Order of Business Will Shape Your Organization, Your Management Style, and Your Life. Boston: Harvard Business School Press.

McGrath, J. E. (1984). Groups: Interaction and Performance. Upper Saddle River, NJ: Prentice Hall.

McKay, C. Pollack, E. \& Fitzpayne A. (2019). Automation and a Changing Economy, The Aspen Institute Future of Work Initiative, April, 2019. Available online at: https://assets.aspeninstitute.org/content/uploads/2019/04/Automation-and-a-ChangingEconomy_The-Case-for-Action_April-2019.pdf. Last accessed on 19 April, 2020.

McKibbin, W. J., \& Fernando, R. (2020). The Global Macroeconomic Impacts of COVID-19: Seven Scenarios. SSRN Electronic Journal. doi:10.2139/ssrn.3547729

Meyer, R. D., Dalal, R. S., \& Hermida, R. (2009). A Review and Synthesis of Situational Strength in the Organizational Sciences. Journal of Management, 36(1), 121-140. doi:10.1177/0149206309349309

Oerlemans, W. G. M., \& Bakker, A. B. (2018). Motivating job characteristics and happiness at work: A multilevel perspective. Journal of Applied Psychology, 103(11), 12301241. https://doi.org/10.1037/ap10000318

Pesole A, Urzí Brancati MC, Fernández-Macías E, Biagi F, González Vázquez I (2018) Platform Workers in Europe. JRC Science for Policy Report. Brussels: European Commission.

Scott, B. A., Colquitt, J. A., \& Paddock, E. L. (2009). An actor-focused model of justice rule adherence and violation: The role of managerial motives and discretion. Journal of Applied Psychology, 94(3), 756-769. https://doi.org/10.1037/a0015712 
ONLINE FREELANCING DURING THE COVID-19 PANDEMIC

Shockley, K.M., \& Allen T.D. (2007). When Flexibility Helps: Another Look at the Availability of Flexible Work Arrangements and Work-Family Conflict. Journal of Vocational Behavior (71)3, 479-493. https://doi.org/10.1016/j.jvb.2007.08.006

Silver, H., \& Coldschejder F. (1994). Flexible Work and Housework: Work and Family Constraints on Women's Domestic Labor, Social Forces, (72)4, 1103-1119. https://doi.org/10.2307/2580294

Stephany, F., Dunn, M., Sawyer, S., \& Lehdonvirta, V. (2020). Distancing bonus or downscaling loss? The changing livelihood of US online workers in times of Covid-19. SocArXiv papers. https://doi.org/10.31235/osf.io/vmg34

Stephany, F., Stoehr, N., Darius, P., Neuhäuser, L., Teutloff, O., \& Braesemann, F. (2020b). The CoRisk-Index: A data-mining approach to identify industry-specific risk assessments related to COVID-19 in real-time. arXiv preprint arXiv:2003.12432.

Sundararajan, A. (2016), The Sharing Economy: The End of Employment and the Rise of CrowdBased Capitalism. Cambridge, Massachusetts: MIT Press.

Tuckman, B. W. (1965). Development sequence in small groups. Psychological Bulletin, 63(6), 384-399.

Turner, N., Barling, J., \& Zacharatos, A. (2002). Positive psychology at work. In C. R. Snyder \& S. J. Lopez (Eds.), Handbook of positive psychology (p. 715-728). Oxford University Press.

Vidal, M. (2013). Low-autonomy work and bad jobs in postfordist capitalism. Human Relations, 66(4), 587-612. https://doi.org/10.1177/0018726712471406

Viteles, M. S. (1953). Motivation and Morale in Industry. New York, NY: Norton.

Vroom, V. H. (1964). Work and Motivation. New York, NY: Wiley. 
ONLINE FREELANCING DURING THE COVID-19 PANDEMIC

Wenham, C., Smith, J., \& Morgan, R. (2020). COVID-19: the gendered impacts of the outbreak. The Lancet, 395(10227), 846-848. https://doi.org/10.1016/s0140-6736(20)30526-2

Wheatley, D. (2017). Autonomy in paid work and employee subjective well-being. Work and Occupations, 44(3), 296-328. https://doi.org/10.1177/0730888417697232

Wiswall, M., \& Zafar B. (2018). Preference for the Workplace, Investment in Human Capital, and Gender. The Quarterly Journal of Economics, (133)1, 457-507. https://doi.org/10.1093/qje/qjx035

Wood, A.J. (2016). Flexible Scheduling, Degradation of Job Quality and Barriers to Collective Voice. Human Relations (69)10, 1989-2010. https://doi.org/10.1177/0018726716631396

Wood, A. J., Graham, M., Lehdonvirta, V., \& Hjorth, I. (2019). Good gig, bad gig: autonomy and algorithmic control in the global gig economy. Work, Employment and Society, 33(1), 56-75. https://doi.org/10.1177/0950017018785616

Wood, A. J., Graham, M., Lehdonvirta, V., \& Hjorth, I. (2019b). Networked but Commodified: The (Dis)Embeddedness of Digital Labour in the Gig Economy. Sociology, 53(5), 931950. https://doi.org/10.1177/0038038519828906. 


\section{Table 1}

Summary Statistics

\begin{tabular}{|l|l|}
\hline \multicolumn{2}{|l|}{ Job Classification } \\
\hline Administrative & $43 \%$ \\
\hline Technology & $16 \%$ \\
\hline Creative & $41 \%$ \\
\hline
\end{tabular}

\begin{tabular}{|l|l|}
\hline Gender \\
\hline Female & $64 \%$ \\
\hline Male & $36 \%$ \\
\hline
\end{tabular}

\begin{tabular}{|l|l|}
\hline \multicolumn{2}{|l|}{ Age } \\
\hline Min & 23 \\
\hline 1st Qu. & 30.75 \\
\hline Median & 35.5 \\
\hline Mean & 38.09 \\
\hline 3rd Qu. & 45.25 \\
\hline Max & 75 \\
\hline
\end{tabular}

\begin{tabular}{|l|l|}
\hline Length on Digital Platforms (years) \\
\hline Min & 0 \\
\hline 1st Qu. & 2 \\
\hline Median & 3 \\
\hline Mean & 5.10 \\
\hline 3rd Qu. & 8.00 \\
\hline Max & 20 \\
\hline
\end{tabular}


ONLINE FREELANCING DURING THE COVID-19 PANDEMIC

\section{Table 2}

Summary of Select Survey Questions by Occupation Type

\begin{tabular}{|c|c|c|}
\hline \multicolumn{3}{|c|}{$\begin{array}{l}\text { Q: Is freelance work your primary source of } \\
\text { income? }\end{array}$} \\
\hline & Yes & $\mathrm{No}$ \\
\hline Admin & $41 \%$ & $59 \%$ \\
\hline Creative & $67 \%$ & $33 \%$ \\
\hline Technology & $46 \%$ & $54 \%$ \\
\hline
\end{tabular}

\begin{tabular}{|l|l|l|}
\hline \multicolumn{3}{|l|}{ Q: Do you have health benefits? } \\
\hline & Yes & No \\
\hline Admin & $50 \%$ & $50 \%$ \\
\hline Creative & $30 \%$ & $70 \%$ \\
\hline Technology & $42 \%$ & $58 \%$ \\
\hline
\end{tabular}

\begin{tabular}{|c|c|c|}
\hline \multicolumn{3}{|c|}{$\begin{array}{l}\text { Respondents who indicated difficulty in } \\
\text { securing work on the platform }\end{array}$} \\
\hline & Pre COVID-19 & Post COVID-19 \\
\hline Admin & $8 \%$ & $50 \%$ \\
\hline Creative & $44 \%$ & $88 \%$ \\
\hline Technology & $22 \%$ & $100 \%$ \\
\hline
\end{tabular}

\begin{tabular}{|c|c|}
\hline \multicolumn{2}{|c|}{$\begin{array}{l}\text { Q: In an average week, how many jobs } \\
\text { do you bid on? }\end{array}$} \\
\hline Admin & 9.05 \\
\hline Creative & 6.03 \\
\hline Technology & 5.00 \\
\hline
\end{tabular}

Q: What is your average earnings per week?

\begin{tabular}{|l|l|l|l|}
\hline & Pre COVID-19 & Post COVID-19 & $\%$ Difference \\
\hline Admin & $\$ 403.33$ & $\$ 354.41$ & $-12 \%$ \\
\hline Creative & $\$ 583.33$ & $\$ 406.70$ & $-30 \%$ \\
\hline Technology & $\$ 437.50$ & $\$ 233.33$ & $-47 \%$ \\
\hline
\end{tabular}

Respondents who indicated that their weekly earning is unpredictable

\begin{tabular}{|l|l|l|}
\hline & Pre COVID-19 & Post COVID-19 \\
\hline Admin & $50 \%$ & $60 \%$ \\
\hline Creative & $39 \%$ & $67 \%$ \\
\hline Technology & $38 \%$ & $33 \%$ \\
\hline
\end{tabular}


ONLINE FREELANCING DURING THE COVID-19 PANDEMIC

\section{Figure 1}

Share of Online Labor Market by Country

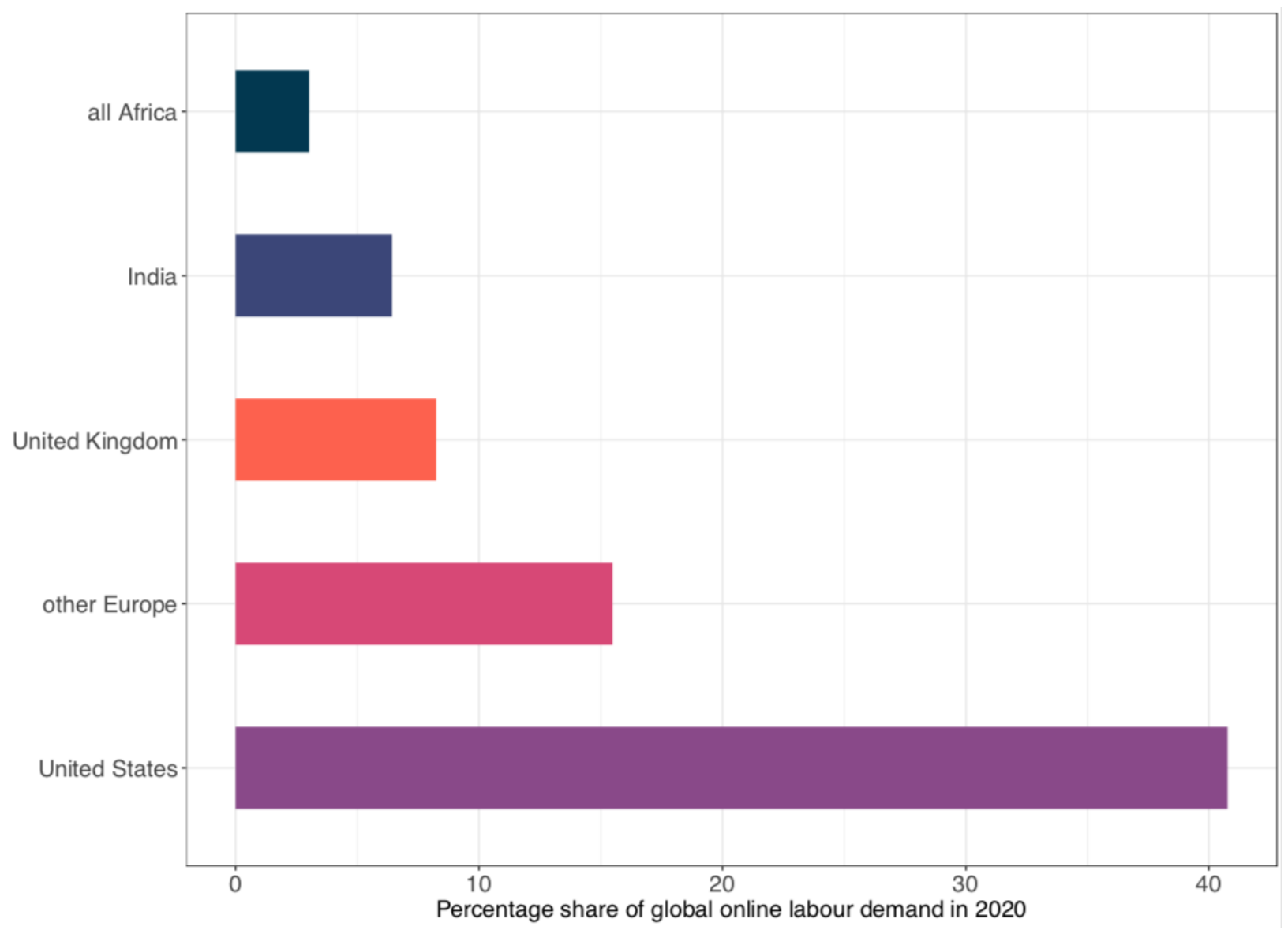

Note: In 2020, the largest share of online labor demand stems from the United States. 
ONLINE FREELANCING DURING THE COVID-19 PANDEMIC

\section{Figure 2}

Demand on Major Online Labor Platforms from the United States, 2018-2020

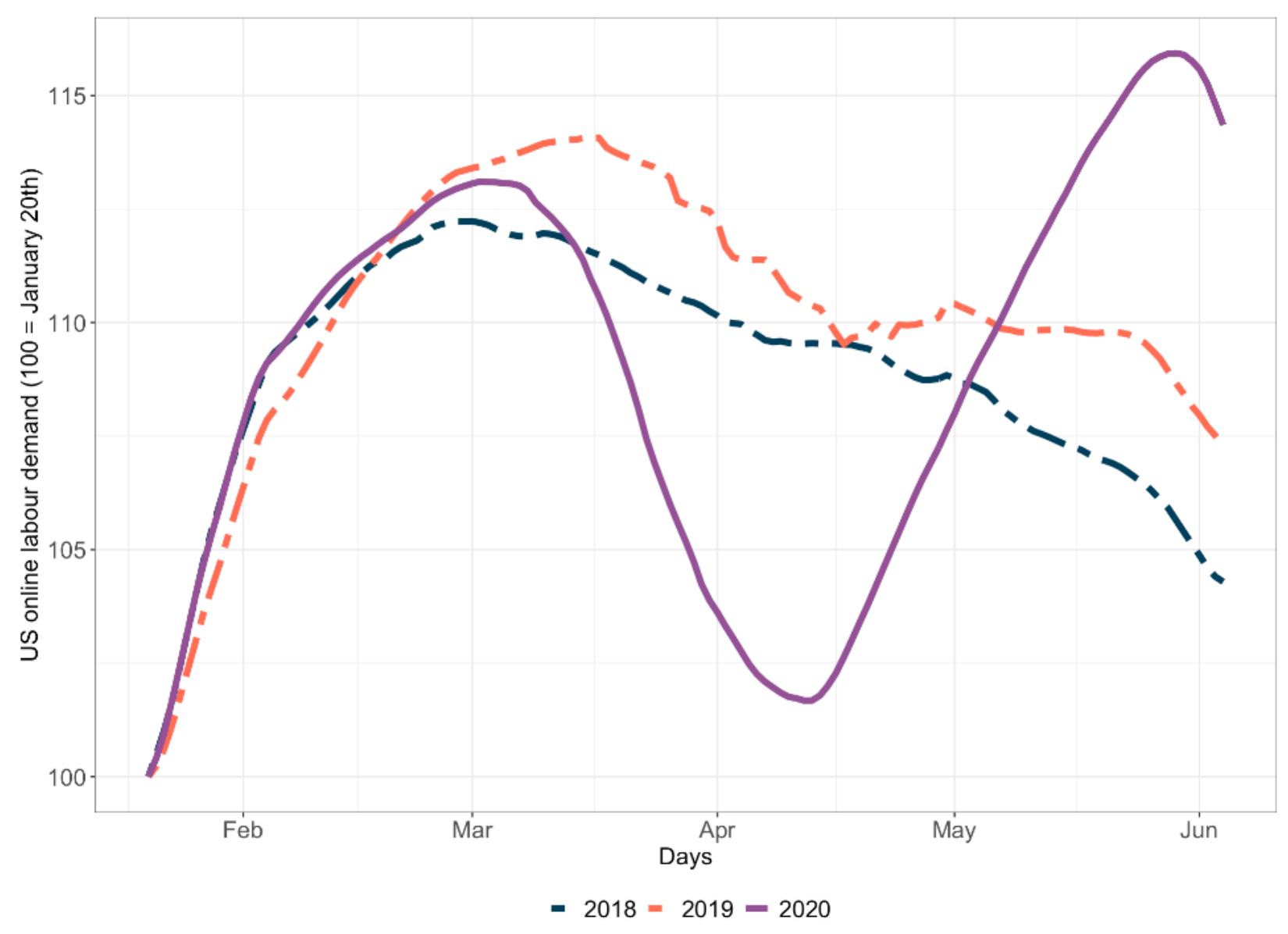

Note: January 20th to June 4th (2018-2020), relative to the start of the year. 
ONLINE FREELANCING DURING THE COVID-19 PANDEMIC

\section{Figure 3}

Online Labor Demand and Number of Registered Workers in the US, by Occupation

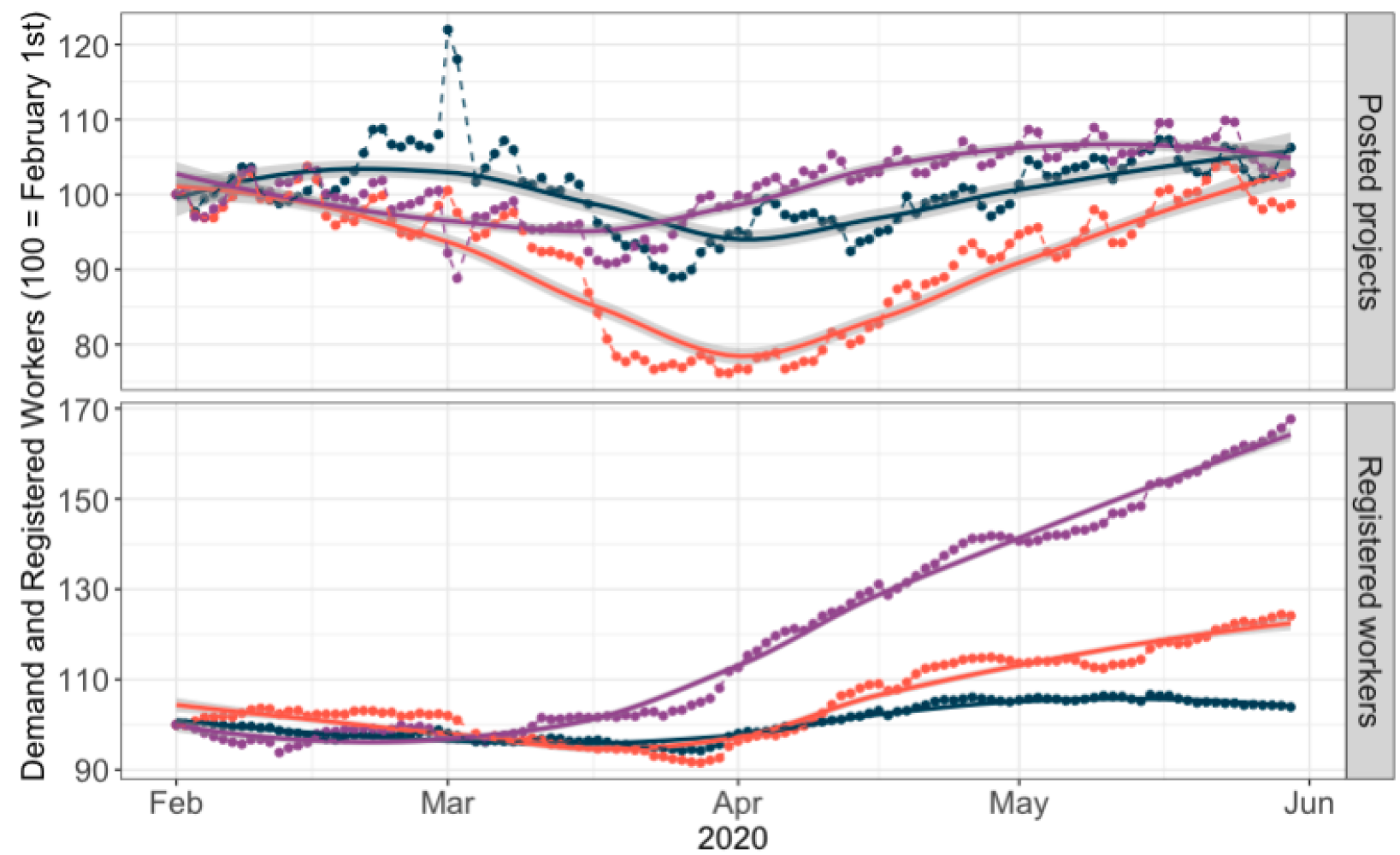

Administrative work $\rightarrow$ Creative work $\rightarrow$ Technology work 
ONLINE FREELANCING DURING THE COVID-19 PANDEMIC

\section{Figure 4}

Average Number of Registered Workers per Project in the US, by Occupation

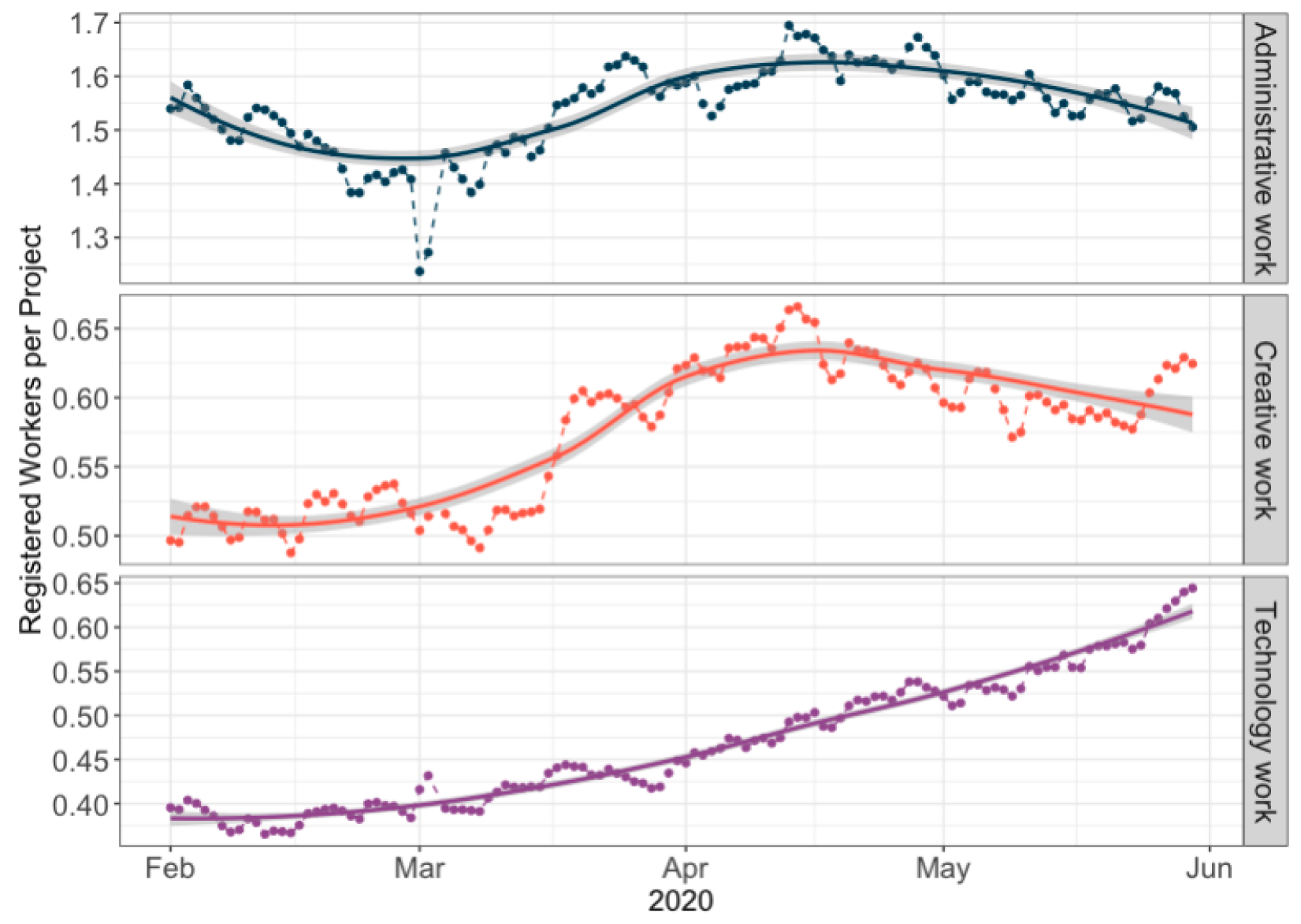


ONLINE FREELANCING DURING THE COVID-19 PANDEMIC

\section{Appendix}

\section{Quantitative Methodology}

The index is constructed by continuously collecting data, in near real-time, on tasks and projects posted on major online labor platforms. The OLI are published as an open data set and an interactive online visualization, updated daily. ${ }^{4}$ The raw data (used in Figures 3 and 4) are collected by periodically sampling workers from four major online labour platforms: Fiverr, Freelancer, Guru, and PeoplePerHour. ${ }^{5}$

\section{Qualitative Methodology}

The study is designed around a carefully constructed sample of people who pursue freelance work as a primary or secondary source of income, and reflect a range of work types, skill levels, experience online, gender, race, and success with this work. Participants are hired and paid as they would for any job found on Upwork. ${ }^{6}$ Once hired, participants complete a 15' survey that provides us an overview of their working plans, outcomes and experiences, and a 45' interview. The interview builds from the survey data and follows a carefully designed protocol of semi-structured questions. ${ }^{7}$ We also did extensive analysis of the survey data collected from the respondents. Specific to comparing with the OLI, the panel study design and this initial analysis, relies on the job classifications provided by Upwork $^{8}$, grouped into three broader categories, as discussed earlier, administrative, technology, and creative work

\footnotetext{
${ }^{4} \underline{\text { http://ilabour.oii.ox.ac.uk/online-labour-index/ }}$

${ }^{5} \mathrm{http}$ ///ilabour.oii.ox.ac.uk/measuring-the-supply-of-digital-labour-how-the-oli-worker-supplement-is-constructed

${ }^{6}$ To reduce the need for Upworkers to bid (as this costs them precious bidding resources), we invite them to the work. Six of 10 do: acceptances and declinations are tracked. Research guidelines require paying those who agree to this job even if they do not finish: this work is voluntary and they can cease working at any time. About one in 10 do not finish. All who begin are rated five stars (as performance ratings matter greatly for online workers). Many of those who have completed the work leave a positive review of the work. There are no negative reviews.

${ }^{7}$ Interviews were done by one of the six members of the digital work research group, a joint effort of Syracuse University and Skidmore College, both in New York. These team members were trained on the protocol and meet frequently and routinely to review the protocol and pursue interim analyses (as is customary in field studies).

${ }^{8}$ Upwork changes its categorization of workers from time to time, making classification an ongoing challenge.
} 